Rapp. Grønlands geol. Unders. 81, 53-56 (1977)

\title{
HIGH PRECISION PHOTOGRAMMETRIC METHODS USED IN GEOLOGICAL MAPPING
}

\author{
Keld S. Dueholm, Asger Ken Pedersen \\ and Finn Ulff-Møller
}

As part of a programme of experimental photogrammetric mapping we present results of geological mapping using advanced photogrammetric instruments in order to test the applicability of such sophisticated methods to geology.

Two experiments are described. They were performed to test the methods on regional and detailed mapping respectively. In both cases vertical aerial photographs at an approximate scale of 1:50 000 were used.

Different types of photogrammetric instruments constructed for and normally employed in topographical mapping were used. For photogrammetric principles and instruments see for instance Schwidefsky \& Ackermann (1976).

\section{Regional mapping \\ Keld S. Dueholm \& Asger Ken Pedersen}

This experiment is exemplified by compilation of the geological map at a scale of 1:50 000 of the Mellemfjord area in south-west Disko (Plate 1).

The instrument used was a first order photogrammetric instrument, Planimat D-2 with external tracing table, EZ-3 and electronic recording unit, Ecomat-11 made by Zeiss. The instrument combines two essential abilities for photogrammetrical work:

(1) It is a stereoscopic plotting instrument, which allows the drawing of continuous structures corrected for all geometrical photo-distortions. Thus it enables the drawing of complex, three-dimensional, geological structures as well as contours in considerable detail.

(2) The instrument digitizes photogrammetric data, i.e. it allows measurements of points in a stereoscopic model with accuracy and speed collaterally with the drawing of the continuous structures. The results are recorded automatically in model coordinates. Thus structural information such as strike and dip of strata, faults and strata thicknesses is easily calculated.

The working principles are as follows: two aerial photographs (diapositives) are inserted in the instrument to form a stereoscopic model and oriented after photogrammetric principles. The model is tied to the geodetic point system through measurement of at least three coordinated points. During the work a measuring point is moved around continuously in the stereoscopic model, simultaneous automatic drawing is made on the coupled tracing table and point coordinates are registrated as required.

4 Rapport nr. 81 


\section{Procedure}

For the photogrammetric interpretation geological compilations carried out by one of the authors (AKP) on enlarged aerial photographs were used. The compilation was based on geological field work together with information from colour slides and oblique and vertical aerial photographs.

Twelve pairs of aerial photographs at an approximate scale of 1:50 000 (Geodetic Institute, Copenhagen) covering an area of about $400 \mathrm{~km}$ in south-western Disko were used in the experiment. The geology and the resulting map are described by Pedersen (this report). As a topographic base an unpublished map at the scale of 1:100 000 from the Geodetic Institute was used and the geodetic point system of this map was employed for orientation of the stereoscopic models.

The map sheet was enlarged to the scale 1:50 000 and transferred to a scribing sheet which was placed on the tracing table. The geological boundaries were thus drawn directly on the topographic base, allowing a continuous check between the geological structures and the contours on the topographic map.

Working capacity was about one stereoscopic model per day (equivalent to $25-30 \mathrm{~km}^{2}$ ) including the drawing of the geological boundaries and measurements of 20-100 points for structural work. The relative precision obtained was about $0.5 \mathrm{~m}$ in both the horizontal plane and altitude. The absolute accuracy was less good depending upon the geodetic point system available for the area.

During the work the photogrammetrist (KSD) began each day by orientating the model. Subsequently the major part of the geological boundaries were drawn using the geological compilations on the enlarged photographic prints. During short visits the geologist resolved eventual queries and inspected the model for new geological information. After this a number of points were selected for measuring. When the stereoscopic model was properly oriented in the instrument this could easily be operated by the geologist.

\section{Experiences and results}

The stereoscopic tracing equipment was very convenient for drawing of continuous geological boundaries. Compared to simple tracing instruments (Stereosketch, Sketchmaster) normally used for geological photointerpretation, this method was considerably more accurate and no more time-consuming for the geologist. The true scale and the correct levelling of the model was a help in geological interpretation, since geological boundaries could be searched for at precalculated levels.

The optical quality of the instrument and the application of high resolution diapositives facilitated the use of the maximum amount of information contained in the photographs and numerous geological details appeared that were not visible on the contact paper prints.

The high precision of the coordinate recording system enable the following to be carried out: (a) the computation of accurate strikes and dips; (b) faults with minor displacements were recorded; (c) altitudes of marine terraces were obtained; (d) detailed surveying of sections through the stratigraphic sequences were carried out (fig. 6); and (e) the recorded thickness variation of a single lava flow made the construction of an isopach map possible (fig. 19), and permitted the volume of this particular lava flow to be estimated. 
The instrument could, if required, be used for the drawing of detailed maps on a much larger scale, also with a good relative accuracy.

However, it was not possible in this project to make use of many of the facilities of the instrument which are used in topographic mapping. Therefore we conclude that a secondorder photogrammetric instrument equipped with coordinate recording device would have served this mapping project with equally good results.

\section{Detailed mapping \\ Keld S. Dueholm \& Finn Ulff-Møller}

An area of $10 \mathrm{~km}^{2}$ covering part of a subvolcanic intrusive complex in north-west Disko (Hammers Dal Complex; Pedersen, 1975; Ulff-Møller, this report) was selected as the test area.

During the regional mapping of the north-western part of Disko on a scale of 1:100 000 by A. K. Pedersen (map sheet 70 V. 1 S, Qutdligssat) the Hammers Dal area appeared to be of special economic interest and for its assessment a detailed topographic and geological map was required. The existing topographic base $(70 \mathrm{~V} .1 \mathrm{O})$ on a scale of $1: 50000$ with $50 \mathrm{~m}$ contour intervals was insufficient for detailed geological work. The available vertical aerial photographs at an approximate scale of 1:40000 (photographs no. A95/163 081-082-083 taken by USN in 1953). The aim of the experiment was to draw out as much information as possible from these photographs.

\section{Instrumentation}

The instruments applied were: (a) a stereocomparator, Stecometer made by Zeiss, Jena, which permits very accurate point measurements in a stereoscopic model, the results being presented in coordinates automatically recorded on paper tape for datamatic processing; (b) a second-order stereoscopic plotting instrument, Aviograph B8, without external tracing table, made by Wild.

\section{Photogrammetric procedure}

For structural work and accurate surveying of the Hammers Dal Complex point measurements were carried out in the stereocomparator. With a magnification of 14 times the stereoscopic model had a scale of approximately 1:3000 which allowed detailed geological interpretation. Colour slides and field data were used as further support during interpretation. In two days a total of 500 points were measured by the geologist (FU-M) collaterally with the interpretation. By means of a computer programme these data were converted into coordinates in a geodetic coordinate system based on the published topographic map $(70 \mathrm{~V} .1 \mathrm{O})$. The relative standard error of the coordinates was $0.6 \mathrm{~m}$ in the horizontal plane and $1.0 \mathrm{~m}$ in altitude. By the use of new photographs and a more experienced operator the accuracy of the measurements could be improved threefold.

The plotting instrument was used in order to trace the geological structures in true orthogonal projection. The tracing of the map was limited to a scale of 1:20 000 due to the lack of an external tracing table. The stereoscopic model was oriented and tied to the geodetic coordinate system through the stereocomparator measurements and contours with $25 \mathrm{~m}$ intervals were drawn by the photogrammetrist (KSD). The rather large contour 
interval was judged sufficient as only a visual impression of the terrain was required. The geologist traced the geological structures. All tracing work was carried out within two days.

\section{Application of the photogrammetric data}

With the aid of computer programmes and the point data the orientation of the lavas, in which the Hammers Dal Complex intruded, was computed. Relevant point data were converted into profile coordinates and used together with a few field measurements in the construction of detailed sections through some of the intrusions (figs 12 \& 13 , Ulff-Møller, this report).

As the amount and accuracy of the information obtained by the comparator measurements was considerable it was found justified to enlarge the topographical and geological tracings to a scale of $1: 4000$. For the sake of convenience the map is reproduced as Plate 2 at a scale of $1: 15000$.

\section{Experience}

The lack of accurate and detailed topographic maps was no limitation and contours were produced as a mere detail to geological work.

Colour slides taken in the field were found very valuable for interpreting the aerial photographs in sufficient detail.

Careful planning, both in the field and in the laboratory, of the points to be measured would increase the speed of point measuring considerably.

For geological purposes maps and cross-sections even more detailed than the present ones could, if reqiured, be produced up to about a hundred times the scale of the original photographs if new photographs are used.

The use of a digitized plotting instrument as described in the previous experiment would have facilitated the work considerably.

\section{Conclusions}

From the two experiments we conclude that a second order photogrammetric instrument equipped with an automatic electronic coordinate recording device would serve geological applications and that such an instrumnet would be ideal for future mapping projects in well exposed terrains in Greenland and comparable areas.

The accuracy of such a second order instrument is somewhat poorer than that of the Stecometer and the Planimat $\dot{\mathrm{D}}-2$ but is judged to be sufficient for most geological purposes. An advantage of this type of instrument is that it could be handled by a geologist after a short period of training.

\section{Acknowledgements}

The authors wish to thank the Royal Veterinary and Agricultural University, Copenhagen, and the Technical University of Denmark for the use of their facilities.

\section{References}

Pedersen, A. K. 1975: New mapping in north-western Disko, 1972. Rapp. Grønlands geol. Unders. 69, 25-32.

Schwidefsky, K. \& Ackermann, F. 1976: Photogrammetrie. 384 pp. Stuttgart: B. G. Teubner. 